Int. J. Speleol. 16 (1987), pp. 69-78

\title{
PALEOENVIRONMENTAL DATA FOR N. W. GEORGIA, U.S.A., FROM FOSSILS IN CAVE SPELEOTHEMS
}

\author{
George A. Brook ${ }^{\star}$, Eugene P. Keferl ${ }^{\star \star}$ and Rudy J. Nickmann ${ }^{\star \star \star}$
}

\section{SUMMARY}

Pollen grains and gastropod shells in two speleothems from Red Spider Cave, Georgia indicate that c. 10,000 yr B.P. the vegetation near the cave was Mixed Mesophytic Forest. Conditions were cooler and moister than today and a shallow pond existed in the doline above the cave. As these findings support palynologic evidence from nearby pond sites it is clear that cave speleothems are a potential source of paleoecological data to c. 350,000 yr. B.P.

\section{INTRODUCTION}

Cave speleothems (stalactites, stalagmites and columns) have become increasingly important in paleoenvironmental research because they can provide paleomagnetic, paleotemperature and paleohydrologic data (SCHWARCZ ET AL., 1976; LATHAM ET AL., 1979; BroOK, 1982). Most importantly, any data obtained from speleothems can be placed in an accurate chronologic framework because the calcite of these formations is dateable by the ${ }^{14} \mathrm{C}$ and ${ }^{234} \mathrm{U} /{ }^{230} \mathrm{Th}$ methods to c. 50,000 and c. 350,000 yr. B.P., respectively. However, despite the finding that speleothems may contain large numbers of pollen grains (BASTIN, 1978), there have been few studies to ascertain the usefulness of fossils in cave formations as paleoenvironmental indicators. Studies of Red Spider Cave, Georgia, begun in 1982, have demonstrated that speleothems may contain abundant fossils that can provide important, dateable, paleoenvironmental information.

* Department of Geography, University of Georgia, Athens, Ga., 30602

* * Department of Natural Sciences and Mathematics, Brunswick College, Brunswick, Ga., 31523

** 88 Bogert Place, Bergenfield, N. J., 07621 
Red Spider Cave (elev. $274 \mathrm{~m}$ ) is located in Johnson's Crook, Dade County, Georgia (Fig. 1). The entrance is on the northwest-facing slope of a resistant ridge at the base of Lookout Mountain. The cave, in limestones, is $135 \mathrm{~m}$ long with a vertical relief of $8 \mathrm{~m}$. One passage, Red Spider Crawl, passes beneath a doline $15 \mathrm{~m}$ deep in the sandstones and shales which cap the ridge in which the cave has developed. After rain, water enters Red Spider Crawl through the main swallet of the doline. The cave was once almost totally filled with clastic sediments up to $3 \mathrm{~m}$ thick. Remnants of this fill are still evident on many passage walls. The mean annual temperature at the cave is $14.9^{\circ} \mathrm{C}$ and the annual precipitation is $1,427 \mathrm{~mm}$.

When sectioned, a stalagmite (RS-3) and a column (RS-4) recovered from Red Spider Crawl were found to contain numerous grastropod shells (Fig. 2). Samples of calcite were taken from these formations for pollen analysis and for ${ }^{14} \mathrm{C}$ dating. Assuming that the speleothem calcite was deposited with 85\% modern carbon (FRANKE AND GEYH, 1971; COOKE AND VERHAGEN, 1977; HENNIG ET AL., 1980), RS-3 is of very early Holocene age $(9,900 \pm 260$ yr B.P.-UGa 3341) and RS-4 of late Glacial age $(10,880 \pm 990 \mathrm{yr}$ B.P.-UGa 3986).

\section{THE GASTROPOD SHELLS}

Speleothems RS-3 and RS- 4 were cut into $1 \mathrm{~cm}$ thick slabs, 110 intact gastropod shells or gastropod shell fragments were observed on the slab surfaces (Table 1). Five different gastropod species were identified. Eighty specimens were of the Genus Carychium. Only a small number could be identified to the species level but the available evidence suggests that all are the species Carychium exile (LEA, 1842). Ten specimens belong to the Family Zonitidae, at least seven of these have been identified as Hawaiia

Table 1 - Gastropod Shells in Two Speleothems, Red Spider Cave.

\begin{tabular}{|l|c|c|c|c|c|c|c|}
\hline Speleothem & Carychium & $\begin{array}{c}\text { Hawaiia } \\
\text { minuscula }\end{array}$ & $\begin{array}{l}\text { Unknown } \\
\text { Zonitidae } \\
\text { Species }\end{array}$ & $\begin{array}{l}\text { Unknown } \\
\text { Zonitidae } \\
\text { Species } 2\end{array}$ & $\begin{array}{c}\text { Unknown } \\
\text { Fresh-water } \\
\text { Species }\end{array}$ & $\begin{array}{c}\text { Misc. Unknown } \\
\text { Species } \\
\text { \& Fragments }\end{array}$ & Total \\
\hline RS-3 & 39 & 2 & 0 & 1 & 0 & 7 & 49 \\
\hline RS-4 & 41 & 5 & 2 & 0 & 1 & 12 & 61 \\
\hline Total & 80 & 7 & 2 & 1 & 1 & 19 & 110 \\
\hline
\end{tabular}




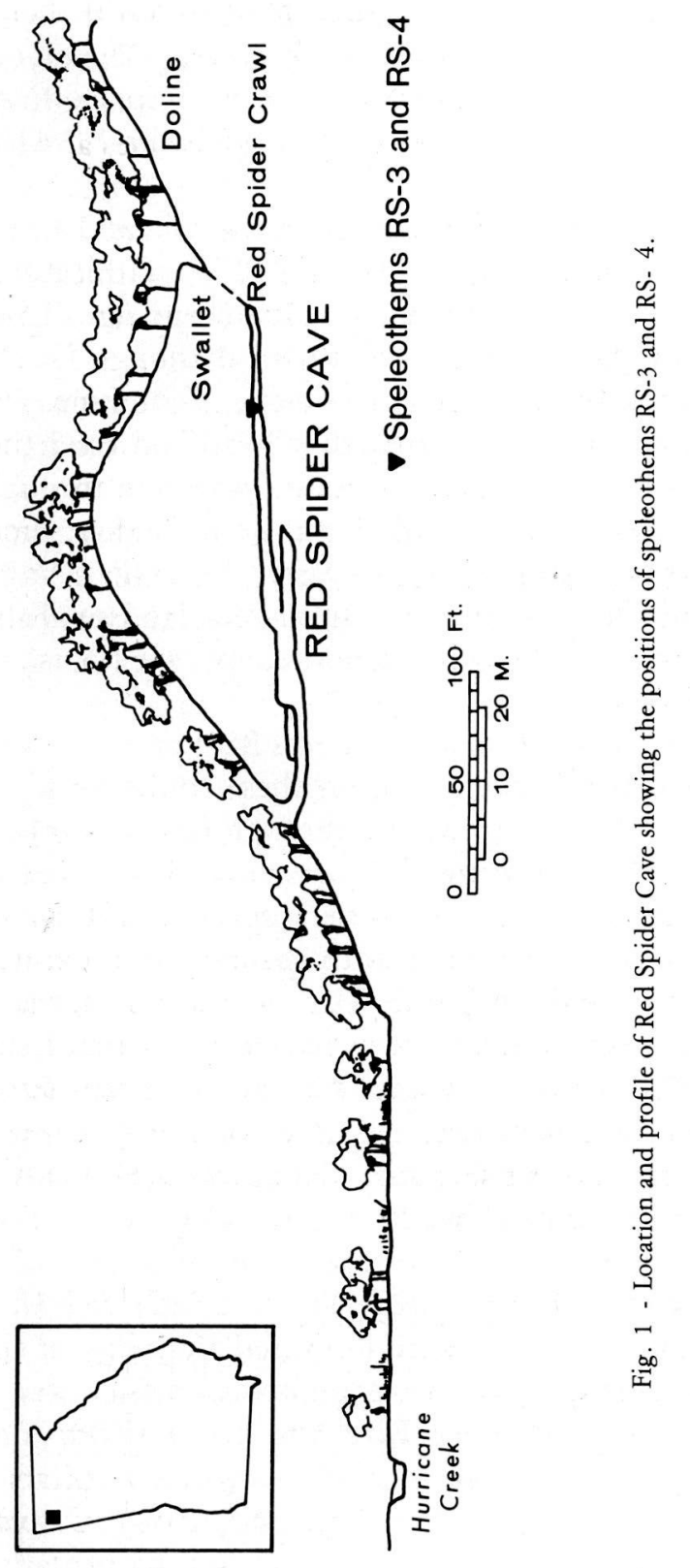


minuscula (BINNEY, 1840), the other specimens could not be identified to the species level. Two Zonitidae specimens in speleothem RS-4 are too small and the whorls too narrow to be $H$. minuscula, and one specimen in speleothem RS-3 is too large to be this species. In speleothem RS-4 another unknown species $1.6 \mathrm{~mm}$ high, $0.75 \mathrm{~mm}$ wide, with 3.5 whorls, appears to be a freshwater gastropod.

Shells and living specimens of $H$. minuscula and $C$. exile have been discovered previously in caves (MORRISON, 1939; HUBRICHT, 1941, 1964), and also in cave clastic sediments of Pleistocene age (LAROCQUE, 1967; PARMALEE, 1967; GUILDAY ET AL., 1978). Although HUBRICHT (1964) reports $C$. exile in seven caves in Kentucky, Tennessee, and Alabama in sufficient numbers to suggest that they lived and bred there, it appears that in most cases specimens in caves are washed in through the entrance or through fissures in the roof. As far as we are aware, there has been no previous report of large numbers of gastropod shells being found in cave stalagmites and columns, although numerous land snail shells have been discovered in layers of flowstone deposited on cave floors (GILLIESON AND MOUNTAIN, 1983).

As some of the shells in speleothems RS-3 and RS- 4 were broken, the gastropods were clearly not living on these formations. The shells were transported into the cave (probably through fissures in the roof) after the animals had died. $C$. exile and $H$. minuscula shells are extremely delicate so that the perfect preservation of several specimens is convincing evidence that the shells are contemporary with speleothem deposition and do not represent reworked older deposits. The shells and shell fragments show no evidence of the degradation to be expected if they had resided in the acid soil layer (on shales) above the cave for any significant length of time.

H. minuscula and C. exile are most commonly found in leaf mould and forest debris in wet and moist habitats. Today, both species inhabit moist litter in the doline above Red Spider Cave. Of 254 gastropod shells in five litter samples taken from the slopes and floor of the doline, 57 $(22.4 \%)$ were of the species C. exile, and $5(2.0 \%)$ were $H$. minuscula. No fresh-water gastropod shells were recovered from any of the samples. $H$. minuscula has been recorded from numerous mesic forest associations in various parts of North America. River and stream floodplains and lake and pond shores appear to be common $H$. minuscula habitats (BAKER, 1911; Oughton, 1948; DeXter, 1950; LeOnARD, 1959). C. exile has been recorded in a wide variety of plant communities, particularly deciduous forest, and was collected from the moist areas within these communities (BA- 
Ker, 1911; SMITH, 1928; KefERL, 1975; CONEY ET AL., 1982). Significantly, both $H$. minuscula and $C$. exile are conspicuously absent from most coniferous forest communities and from xeric deciduous forest communities.

Abundant shells of $H$. minuscula and $C$. exile in speleothems RS-3 and RS-4 suggest that by the late Glacial and early Holocene, the predominantly coniferous forest of full Glacial time (DELCOURT AND DELCOURT, 1981; WATTS, 1983) had been replaced by a mesic deciduous forest. The gastropods were probably living in moist forest litter on the slopes of the doline above the cave and were washed into Red Spider Crawl through fissures in the roof (Fig. 1). The presence of what appears to be a freshwater gastropod shell in speleothem RS-4 raises the possibility that water was ponded in the doline above Red Spider Cave during late Glacial times. Ponding may have occurred because swallets, which normally drain

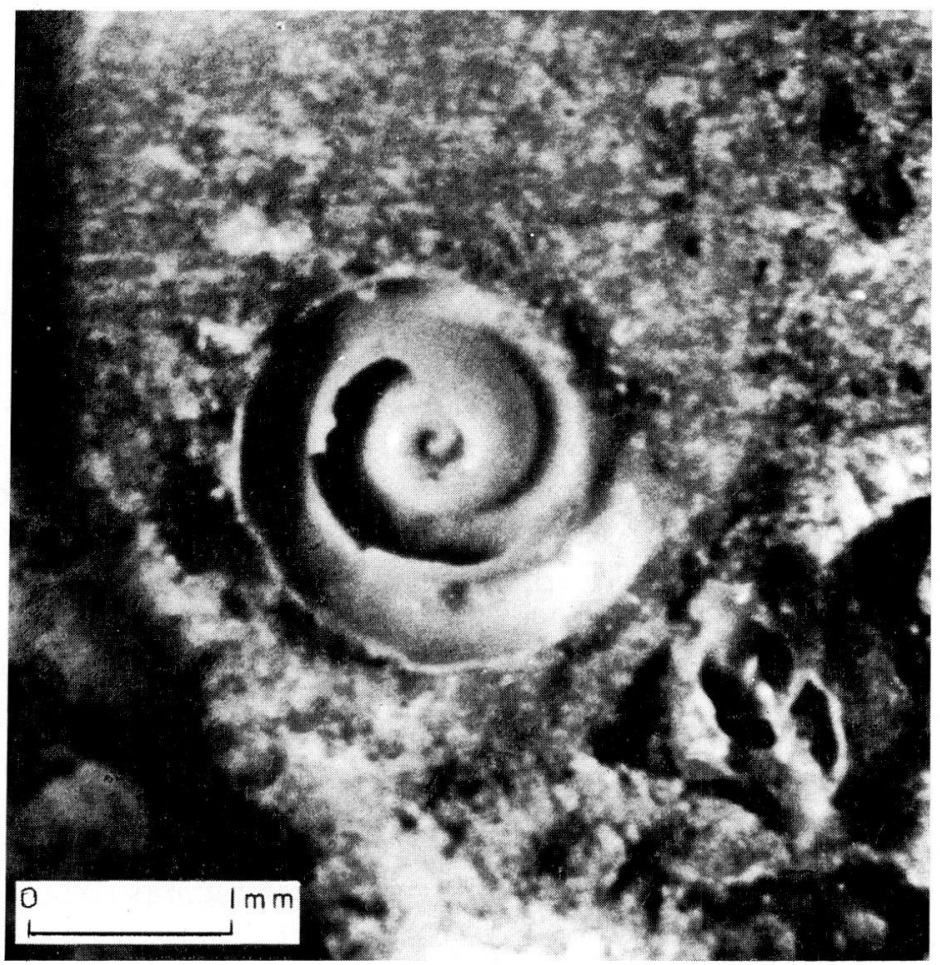

Fig. 2 - Section of speleothem RS-4 showing shells of $H$. minuscula (center), and C. exile (lower right). 
the doline, became blocked with sediments perhaps at a time when the passages of the cave were also largely filled with clastic debris. If ponded water was present in the doline c. 11,000-10,000 yr B. P., it is possible that large numbers of $H$. minuscula and $C$. exile were living along the moist shore of the pond. Pond shores are favored habitats of both species today.

\section{THE POLLEN SPECTRA}

Samples of calcite from speleothems RS-3 and RS-4 yielded 537 and 384 pollen grains, respectively (Fig. 3). Based on studies by BASTIN (1978) it is evident that speleothem pollen spectra reflect the local vegetation near the cave rather than the regional pollen rain. Therefore, pollen spectra for the two Red Spider Cave speleothems are considered to provide evidence about vegetation immediately above and near the cave at the time of speleothem deposition. Long residence in the oxidizing environment of the soil above the cave, where pollen degradation is rapid, is not indicated by the good preservation of the pollen grains recovered. Therefore, these plant microfossils are believed to be contemporary with speleothem deposition and, like the much larger gastropod shells in these formations, are believed to have been washed into the cave through fissures in the roof.

Speleothem RS-4, dated to $10,880+990$ yr. B. P., contained $70.6 \%$ arboreal and $21.2 \%$ non-arboreal pollen. Quercus (oak) dominated the pollen sum with $32.6 \%$ of the pollen. Pinus (pine), Ostrya-Carpinus (hophornbeam), and Ulmus (elm) followed with $16.2 \%, 11.5 \%$ and $6.3 \%$ of the pollen, respectively. Gramineae (grasses), Cyperaceae (sedges), and Ambrosia (ragweed) made up the bulk of the non-arboreal pollen content contributing $11.2 \%, 5.0 \%$, and $2.6 \%$ of the total, respectively. Speleothem RS-3 contained $87.9 \%$ arboreal and only $8 \%$ non-arboreal pollen suggesting a more closed forest cover near the cave by $9,900 \pm 260 \mathrm{yr} B$. P. The forest must have been largely oak ( $42.3 \%$ of the pollen sum) with pine contributing only $6.7 \%$ of the pollen rain. Oak and pine made up only $63.3 \%$ of the arboreal pollen in speleothem RS-3, compared to $88 \%$ in speleothem RS-4, reflecting the increased importance of other deciduous taxa such as Ulmus, Fraxinus (ash), Fagus (beech), Liriodendron (tulip tree), Carya (hickory), Corylus (hazel), and Ostrya-Carpinus which contributed $14.9 \%, 6.4 \%, 3.5 \%, 4.5 \%, 2.8 \%, 1.3 \%$ and $1.1 \%$ to the pollen sum, respectively. Gramineae $(3.2 \%)$ and Cyperaceae $(1.7 \%)$ were the main non-arboreal pollen types in speleothem RS-3. 
PALEONVIRONMENTAL DATA

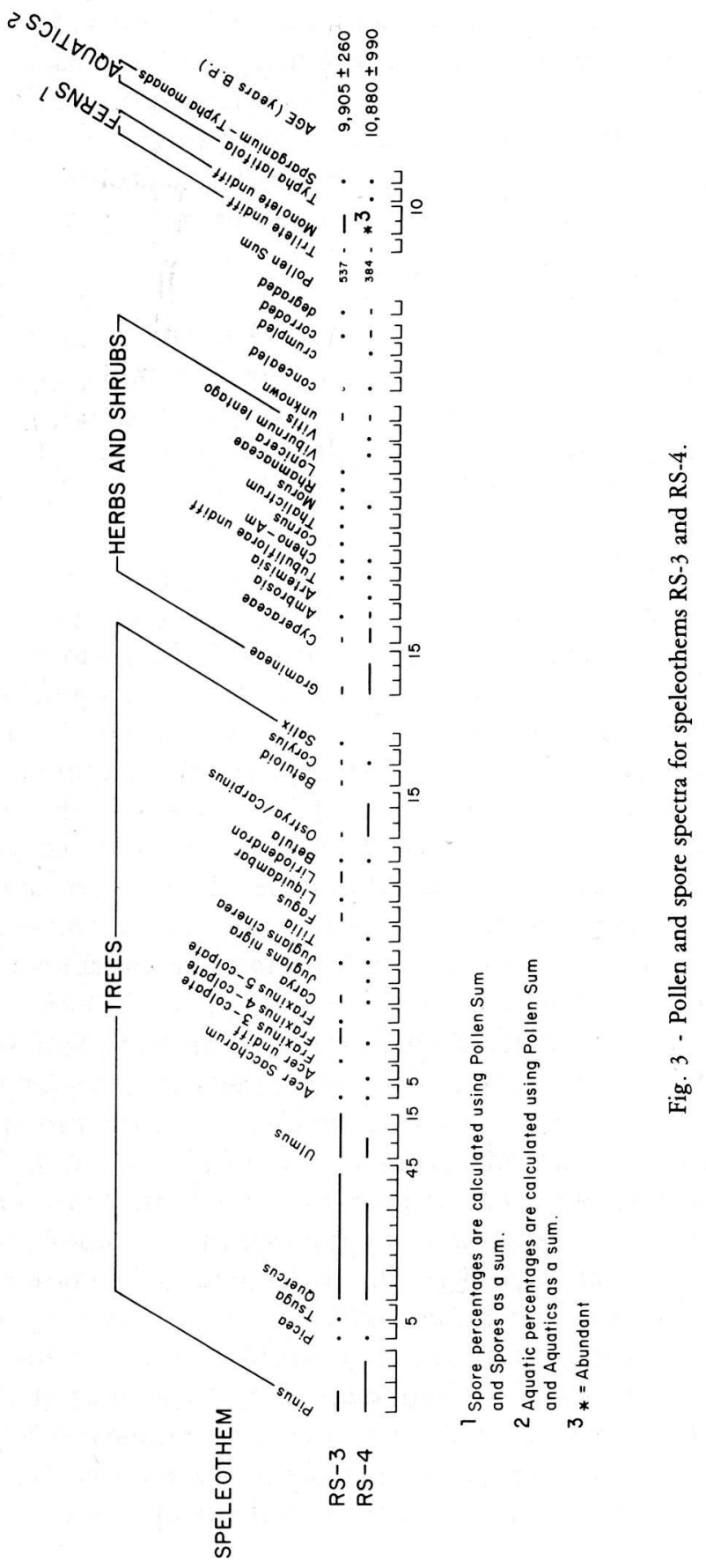


The speleothem pollen spectra indicate that in late Glacial and early Holocene times the vegetation near Red Spider Cave was a largely deciduous forest. Lower non-arboreal pollen percentages and lower percentages of pine pollen in speleothem RS-3 suggest a trend in late Glacial times from a relatively open Oak-Hickory-Pine Forest at 10,880 $\pm 990 \mathrm{yr}$ B.P. to a closed Mixed Deciduous Forest more dominated by deciduous taxa at $9,900 \pm 260$ yr B.P. Picea (spruce) pollen in both speleothems and Tsuga (hemlock) pollen in RS-3 imply more available moisture and a cooler climate than today in late Glacial and early Holocene times. Small percentages of aquatic pollen (Typha latifolia (cat-tail) and Sparganium (bur-reed)) suggest that there was standing water nearby - the most likely location being in the floor of the doline above the cave.

\section{CONCLUSIONS}

The pollen grain and gastropod shell assemblages in two speleothems from Red Spider Cave, Georgia both indicate that in late Glacial and early Holocene times the vegetation near the cave was deciduous forest. The pollen grains and gastropod shells were probably transported into the cave by water percolating through fissures in the roof. The pollen evidence suggests that between 10,880 and 9,900 yr B.P. the vegetation changed from an Oak-Hickory-Pine Forest to a Mixed Deciduous Forest and that throughout the period water may have been ponded in the doline above the cave. A possible freshwater gastropod shell in speleothem RS-4 also suggests standing water in the doline.

DELCOURT and DELCOURT (1981) and WATTS (1983) contend that in the late Glacial and early Holocene a cool, moist climate with abundant moisture in the growing season favored the widespread expansion of species-rich, Mixed Deciduous Forest from $34^{\circ}$ to $37^{\circ} \mathrm{N}$ latitude in eastern North America. This area was dominated in the winter by the Pacific Airmass and in the summer by the Maritime Tropical Airmass (DELCOURT AND DELCOURT, 1984). The speleothem pollen evidence of Mixed Deciduous Forest at Red Spider Cave (lat. $34^{\circ} 53^{\prime} \mathrm{N}$ ) c. 10,000 yr B.P. is in essential agreement with this argument.

In summary, studies at Red Spider Cave have shown that macrofossils and microfossils may be present in cave speleothems in large numbers. The evidence obtained from two Red Spider Cave speleothems, indicating a Mixed Mesophytic Forest vegetation near the cave in early Holocene ti- 
mes, is in essential agreement with palynological data obtained from nearby pond sites (DELCOURT AND DELCOURT, 1981; WATTS, 1983). This suggests that fossils in cave speleothems, which have not drawn significant scientific interest to date, could be a valuable source of paleoecological data to c. $350,000 \mathrm{yr}$ B.P. - the range of the ${ }^{234} \mathrm{U} /{ }^{230} \mathrm{Th}$ dating method.

\section{ACKNOWLEDGEMENTS}

This research was supported by a grant and an M. G. Michael Award from the University of Georgia Research Foundation to George A. Brook. The authors would like to thank Jerry Davis, James Merry, and Diane Brook for their considerable help with the project.

\section{REFERENCES}

BAKER H. B., 1911: A biological survey of the sand dune region on the south shore of Saginaw Bay, Michigan. Michigan Geol. Biol. Surv. 4, Biol. Ser., 2: 121-176.

BASTIN B., 1978: L'analyse pollinique des stalagmites: une nouvelle possibilité d'approche des fluctuations climatique du Quaternaire. Ann.ls Soc. géol. Belg., 101: 13-19.

BROOK G. A., 1982: Stratigraphic evidence of Quaternary climatic change at Echo Cave, Transval, and a paleoclimatic record for Botswana and northeastern South Africa. Catena, 9: 343-351.

Coney C.C., TARPley W. A., WARden J. C. AND NAGEL J. W., 1982: Ecological studies of land snails in the Hiwassee River basin of Tennessee, U.S.A. Malacol. Rev., 15: 69-106.

COOKE H. J. AND VERHAGEN B. TH., 1977: The dating of cave development - an example from Botswana. Proc. 7th int. speleol. Congr., 122-124.

Delcourt P. A. And Delcourt H. R., 1981: Vegetation maps for eastern North America: $40,000 y r$. B. P. to the present. In Geobotany II (ed. R. C. Romans), Plenum Press, New York, 123-165.

DelCOURT P. A. AND DelCOURT H. R., 1984: Late Quaternary paleoclimates and biotic responses in eastern North America and the western North Atlantic Ocean. Palaeogeogr. Palaeoclimatol. Palaeoecol., 48: 263-284. 
DEXTER R. W., 1950: Distribution of the mollusks in a basic bog lake and its margins. Nautilus, 64: 19-26.

FRANKE H. W. AND GEYH M. A., 1971: Radiokoblenstoff-Analysen an Tropfsteinen. Umschau, 71: 91-92.

GILLIESON D. AND MOUNTAIN M-J., 1983: Environmental history of Nombe rockshelter, Papua New Guinea Highlands. Archaeol. Oceania, 18: 45-53.

Guilday J. E., hamilton H. W., Anderson E., Parmalee P. W., Faulkner C. H., Hill F. C. AND VAN Dam G. H., 1978: The Baker Bluff Cave deposit, Tennessee, and the Late Pleistocene faunal gradient. Bull. Carnegie Mus. Nat. Hist., 11: 67 p.

HeNNig G. J., BANGERT U., HeRR W. AND FREUNDLICH J., 1980: Uranium series dating of calcite formations in caves: recent results and a comparative study on age determinations via ${ }^{230} \mathrm{Th} /{ }^{234} \mathrm{U},{ }^{14} \mathrm{C}$, TL and ESR. Rev. Archaeom., 4: 91-100.

HUBRICHT L., 1941: The cave mollusca of the Ozark region. Nautilus, 54: 111-112.

Hubricht L., 1964: Land snails from caves of Kentucky, Tennessee and Alabama. Nat. Speleol. Soc. Bull., 26: 33-35.

KeFErL E. P., 1975: An ecological study of the mollusca of the Cedar Bog Nature Sanctuary, Champaign County, Ohio. Dissertation, Ohio State Univ., Columbus.

LA RocQue A., 1967: Pleistocene mollusca of the Ladds deposit, Bartow County, Georgia. Bull. Ga. Acad. Sci., 25: 167-187.

Latham A. G., Schwarcz H. P., Ford D. C. And Pearce G. W., 1979: Paleomagnetism of stalagmite deposits. Nature, 280: 383-385.

LEONARD A. B., 1952: Illinoisan and Wisconsinin molluscan faunas in Kansas. Univ. Kansas Mus. Nat. Hist. Misc. Pub., 20: 224 p.

Morrison J. P. E., 1939: An unusual cave deposit. Nautilus, 53: 45-47.

Oughton J., 1948: A zoogeographical study of the land snails of Ontario. Univ. Toronto Stud., Biol. Ser., 57: 128 p.

Parmalee P. W., 1967: A recent cave bone deposit in southwestern Illinois. Nat. Speleol. Soc. Bull., 29: 119-147.

SChwarcz H. P., Harmon R. S., Thompson P. AND Ford D. C., 1976: Stable isotope studies of fluid inclusions in speleothems and their paleoclimatic significance. Geochim. cosmochim. Acta, 40: 657-665.

SMITH V. J., 1928: Animal communities of a deciduous forest succession. Ecology, 9: 479500 .

WATTS W. A., 1983: Vegetation history of the eastern United States 25,000 to 10,000 years ago. In: Late Quaternary environments of the United States, Vol. 1. The Late Pleistocene (eds. Wright Jr. H. E. and Porter S. C.) p. 294-310 (Univ. of Minnesota Press, Minneapolis). 